\begin{tabular}{c} 
Volume and Issues Obtainable at Center for Sustainability Research and Consultancy \\
Responsible Education, Learning and Teaching in Emerging Economies \\
ISSN: 2708-4310 (E): 2708-4183 \\
Volume 1: No. 1, June 2019 \\
CSRᄃ \\
Journal homepage: www.publishing.globalcsrc.org/relate \\
\hline
\end{tabular}

\title{
Use of ICT and Students' Personal and Social Development at Higher Education Level
}

\author{
${ }^{1}$ Abid Hussain Chaudhry, ${ }^{2}$ Misbah Malik \\ ${ }^{1}$ Professor of Education, Institute of Education and Research, University of the Punjab,Lahore, Pakistan: \\ chabidhussainier@yahoo.co.in \\ ${ }^{2}$ Lecturer, Institute of Education and Research, University of the Punjab, Lahore, Pakistan: \\ misbah.ier@pu.edu.pk
}

\begin{tabular}{ll}
\hline \multicolumn{1}{c}{ ARTICLE DETAILS } & ABSTRACT \\
\hline History & The substantive purpose of this study was to identify the effect of \\
Revised format: May 2019 & using ICT on students' personality development. Population of the \\
Available Online: June 2019 & $\begin{array}{l}\text { study consisted of students of two universities of Lahore. Sample of } \\
\text { the study comprised randomly selected 242 students. A self- } \\
\text { developed and validated instrument was used for data collection. }\end{array}$ \\
\hline Keywords & Instrument comprised two sections one contained demographic \\
Personality Development; & variables and other statements related to personality development of \\
Higher Education & students. A pilot study was conducted to validate the instrument. \\
& The reliability index (cronbach alpha) was .83 which is statistically \\
JEL Classification: & significant. Data were analyzed through SPSS. t- test was run to \\
I23, I29 & identify mean difference in personality development of male and \\
& female students. ANOVA was applied to see mean difference in the \\
& responses of students, regarding their personality development in \\
different programs. Results showed that use of ICT has a profound & effect on Female students' personality. Results of ANOVA revealed \\
that students of BBA department show more effect of ICT on their & personality. Recommendations were made on the basis of findings.
\end{tabular}

(C) 2019 The authors, under a Creative Commons AttributionNonCommercial 4.0

Corresponding author's email address: chabidhussainier@yahoo.co.in

Recommended citation: Chaudhry, A. H. \& Malik, M., (2019). Use of ICT and Students' Personal and Social Development at Higher Education Level. Responsible Education, Learning and Teaching in Emerging Economies, 1(1), 1-8

DOI: $10.26710 /$ relate.v1i1.1116

\section{Introduction}

The usage of information and communication technology (ICT) is increasingly being seen as a major tool for progress. ICT is a force that has changed many aspect of the way we live. The use of ICT in education and training has been a key priority in most EU and OECD countries in the last decade. ICT has had a major impact on the education sector, on organization and on teaching and learning methods.

There is widespread belief that ICTs can and will empower teachers and learners, transforming teaching 
and learning processes from being highly teacher-dominated to student-centered, and that this transformation will result in increased learning gains for students, creating and allowing for opportunities for learners to develop their creativity, problem-solving abilities, informational reasoning skills, communication skills, and other higher-order thinking skills. However, at present limited, explicitly persuasive facts are available to support this belief

Technology has a pivotal role in teachers and students' practices such as promoting collaborative learning, improving communication skills, enhancing teachers and students' motivation through diverse activities and updated information as well as increasing learners' achievement due to the reinforcement and various practices provided in the Internet (Warschauer \&Healey, 1998; Downes, Arthur \&Beecher, 2001). The impact of ICT on learning is currently discussed almost entirely in relation to use of digital media, primarily the World Wide Web. However, ICT impacted on higher education before the widespread use of the Internet. Through the application of print, audio-visual and broadcast media to distance education, it has enabled those with adult roles and responsibilities to continue formal study leading to higher education on a mass scale.

A significant number of pupils think as of ICT instruments altogether supportive in that it helps them on do assignments educators see that. ICT empowers scholars for uncommon needs or challenges. It also helps to decrease those social disparities between pupils, since they partake) energizes groups in place should attain a provided for errand. Understudies also expect responsibilities as they use ICT to their worth of effort through advanced portfolios or ventures. Additionally, the study indicated that ICT need huge effect looking into students' personal advancement.

Clinched alongside An report entitled educating support and taking in with ICT. Analysts working in the field illustrate how ICT could Push educating and learning (Gale \& Watson 2002). Scholars discover new explanatory skills, including upgrades to perusing perception. ICT also create exactly composing skills: spelling, grammar, punctuation, altering and re-drafting (Lewin, Cooper, Ericsson \&Rupp, 2000). At present new innovations urge free and dynamic learning, Also students' obligation to their Taking in (Passey, 1997). ICT turns out that scholars who utilized instructive innovation felt more fruitful to one school they need aid All the more Inspired will gain more What's more have expanded self- certainty and respect toward oneself. It will be additionally affirmed that large portions people found Taking in over a technology-enhanced setting additional empowering Furthermore much superior to clinched alongside an accepted classroom nature's domain (Pedretti, Mayer-Smith \& Woodrow, 1998).

There need aid various investigations centering on the identity qualities from claiming people or other web clients towards those web usage. Nonetheless, little exploration need inspected those customized improvement for understudies same time utilizing machines to instructive purposes particularly in the Pakistani context.

The ways of ICT need changed how people standardize today. ICT has taken the world closer through Person to person communication destinations. ICT recourses need produced exploring majority of the data easier, Likewise majority of the data can beaccessedthrough onthe web. This serves people who haven't got a library close to their lodging. Through long range informal communication people could converse with family, friends, enthusiasm gatherings and researchers starting with crosswise over that globe. It aides persons who can't move on different put.

ICT need made huge numbers openings for work for people with apply for, ICT dexterity would Right away required for Just about constantly on sort of occupations Also for wide web access, people got to be equipped should cooperation Furthermore worth of effort with others who are a long way from fill in place, working starting with their put need turned into An that's only the tip of the iceberg prevalent decision because of this chance. A portion understudies use The majority of their recreation time utilizing computers, mobile, tabs etc., which might influences their social improvement on account of they don't 
bring social abilities should talk unhesitatingly Previously, school or at work. Due to cooperating with respect to cell telephones alternately utilizing At whatever online networking system over converse with their companions as well as they absence the capacity with convey. A percentage Youngsters need aid also needing clinched alongside perusing aptitudes Likewise nearby libraries would be shut down because of know youngsters not being intrigued by perusing or setting off outside. This influences them progressing great to one school.

Through technology-facilitated approaches, contemporary Taking in settings Not withstanding urge people on make obligation to their Taking in. In the secret word people need get to be altogether agreeable to Taking in through transmitting modes. Understudies bring been prepared on let others exhibit should them the majority of the data that structures the educational module which ruin their individual improvement. Learners utilizing ICTs to Taking in purposes get to be inundated in the transform of taking in Furthermore as an ever increasing amount people utilization workstations as majority of the data wellsprings and cognitive devices (Jonassen\&Reeves, 1996), that impact of the engineering on supporting how scholars discover will keep on going with expansion.

This paper seeks to explore the effect of using ICT on personal and social development of students at higher education level. In particular, the paper will explore the impact ICT with respect to gender and discipline of study. The study will also revealed the use of social media by male and female students, and among students in different programs.

\section{Objectives of The Study}

The study was conducted to achieve the following objectives:

- To identify the use of ICT among student on the basis of gender.

- Recognize the use of ICT among students of different programs.

- To identify effect of using ICT on male and female students' personality development .

- To identify effect of using ICT on students' personality development in different programs.

\section{Methodology}

Following section will discuss the procedures of the study.

\subsection{Population of the Study}

All the students enrolled in two public universitiesof Lahore were the population of the study.

\subsection{Sample and Sampling Technique}

Sample of the study comprised randomly selected 242 students.

\subsection{Instrument}

A self-developed and validated instrument was used for data collection. Instrument comprised two sections one contained demographic variables and other statements related to personality development of students. The factors included to measure the personal and social development of students were students' self-confidence, time management, independence, motivation, performance, social relations, competition and collaboration. A pilot study was conducted to validate the instrument. The reliability index (CronbachAlpha) was .83 which is statistically significant.

\subsection{Data Analysis}

Data were analyzed through SPSS. Descriptive statistics was used to identify use of ICT and personal and social development students at higher education level. $t$ - test was run to identify mean difference in use of ICT and personal and social development of male and female students. ANOVA was applied to see mean difference in the responses of students regarding their personal and social development in different departments. 


\section{Results}

Following section will present the results of data analysis.

Table 1: Descriptive Statistics of Variables under Study

\begin{tabular}{|l|l|l|l|}
\hline Variable & Factors & Frequency & Total \\
\hline \multirow{2}{*}{ Gender } & Male & 94 & 242 \\
\cline { 2 - 3 } & Female & 148 & \\
\hline \multirow{5}{*}{ Program } & Business & 58 & \multirow{3}{*}{242} \\
\cline { 2 - 3 } & Sciences & 66 & \\
\cline { 2 - 3 } & Law & 48 & 242 \\
\cline { 2 - 3 } & Sociology & 70 & \\
\hline Age & $18-30$ & & \\
\hline
\end{tabular}

Table 2: t-Test for Difference in Social and Personal Development of Students on the Basis of Gender

\begin{tabular}{|l|l|l|l|l|l|}
\hline \multicolumn{2}{|c}{} & N & M & SD. Df. MD t-value & sig. \\
\hline \multirow{2}{*}{ Social development } & Male & 94 & 26.64 & $6.46 \quad 240 \quad 1.731 .97$ & .05 \\
\cline { 2 - 7 } & Female & 148 & 24.91 & 6.82 & .00 \\
\hline \multirow{2}{*}{ Personal development } & Male & 94 & 22.70 & $4.06240 \quad 2.353 .62$ & \\
\cline { 2 - 7 } & Female & 148 & 20.35 & 5.40 & \\
\hline
\end{tabular}

Table 2 depicts the results of t-test to identify mean difference in social and personal development of students using ICT on the basis of gender. Value of the table shows that there was significant mean difference in male $(\mathrm{M}=26.64, \mathrm{SD}=6.46)$ and female $(\mathrm{M}=24.91, \mathrm{SD}=6.82)$ students' social development $\mathrm{t}(240)=1.97, \mathrm{p}<.05$. Similarly it is also evident that that there was significant mean difference in personal development of male $(\mathrm{M}=22.70, \mathrm{SD}=4.06)$ and female $(\mathrm{M}=20.35, \mathrm{SD}=5.40)$ students $\mathrm{t}(240)=3.62, \mathrm{p}<.05$.

Table 3: ANOVA to see Difference on the Basis of Programs of Study

\begin{tabular}{|c|c|c|c|c|c|c|}
\hline Variables & & \begin{tabular}{|l|}
$\begin{array}{l}\text { Sum of } \\
\text { Squares }\end{array}$ \\
\end{tabular} & \begin{tabular}{|l} 
Mean \\
Square
\end{tabular} & df. & $\mathrm{F}$ & Sig. \\
\hline & Between Groups & 5031.44 & 1677.15 & 3 & 68.17 & .000 \\
\hline Social development & Within Groups & 5855.57 & 24.60 & 238 & & \\
\hline & Total & 10887.01 & & 241 & & \\
\hline & Between Groups & 1867.93 & 622.64 & 3 & 34.69 & .000 \\
\hline Personal & \begin{tabular}{|l} 
Within Groups \\
\end{tabular} & 4271.14 & 17.95 & 238 & & \\
\hline & Total & 6139.07 & & 241 & & \\
\hline No of social media & Between Groups & 66.18 & 22.06 & 3 & 4.22 & .006 \\
\hline 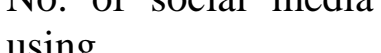 & Within Groups & 1072.06 & 5.23 & 205 & & \\
\hline & Total & 1138.24 & & 208 & & \\
\hline & Between Groups & 156.66 & 52.22 & 3 & 3.74 & .012 \\
\hline Use or internet in & Within Groups & 3099.833 & 13.963 & 222 & & \\
\hline & Total & 3256.496 & & 225 & & \\
\hline
\end{tabular}

Table 3 presents the results of ANOVA to identify mean difference in students' personal and social development, number of social media networks being used by the students and use of internet in hours per day in different programs, e.g. Business, science, law and sociology using ICT. Table revealed that there was significant mean difference in social development $F(3)=68.17$, p $<.05$ and personal development 
$F(3)=34.69, p<.05$ of students enrolled in different programs on the basis of using ICT. There was also significant mean difference on the basis of number of social media being used by the students of different programs $\mathrm{F}(3)=4.22$, $\mathrm{p}<.05$. Analysis also showed that significant mean difference occur in students' responses enrolled in different programs of study on the basis of using internet per day $\mathrm{F}(3)=3.74$, $\mathrm{p}<$ .012

Table 4: Descriptive Values of AVOVA Test for Mean Difference on the Basis of Programs of Study

\begin{tabular}{|c|c|c|c|c|}
\hline \multicolumn{2}{|l|}{ Variables } & \multirow{2}{*}{\begin{tabular}{|l|}
$\mathrm{N}$ \\
\\
58
\end{tabular}} & \multirow{2}{*}{$\begin{array}{l}\mathrm{M} \\
30.0345\end{array}$} & \multirow{2}{*}{\begin{tabular}{|l|} 
SD. \\
\\
5.08512 \\
\end{tabular}} \\
\hline \multirow{5}{*}{ Social development } & Business & & & \\
\hline & Sciences & 66 & 29.8485 & 5.20427 \\
\hline & Law & 48 & 22.5833 & 5.42584 \\
\hline & Sociology & 70 & 19.9143 & 4.23492 \\
\hline & Total & 242 & 25.5785 & 6.72118 \\
\hline \multirow{5}{*}{ Personal development } & Business & 58 & 23.7586 & 3.90820 \\
\hline & Sciences & 66 & 24.1515 & 3.69716 \\
\hline & Law & 48 & 18.6667 & 4.68285 \\
\hline & Sociology & 70 & 18.2571 & 4.63348 \\
\hline & Total & 242 & 21.2645 & 5.04711 \\
\hline \multirow{5}{*}{ Social media in use } & Business & 57 & 3.05 & 2.601 \\
\hline & \begin{tabular}{|l|} 
Sciences \\
\end{tabular} & 66 & 2.36 & 2.117 \\
\hline & Law & 33 & 1.52 & 1.922 \\
\hline & Sociology & 53 & 3.08 & 2.336 \\
\hline & Total & 209 & 2.60 & 2.339 \\
\hline \multirow{5}{*}{ Use of internet in Hours } & Business & 58 & 3.24 & 1.809 \\
\hline & Sciences & 66 & 4.76 & 6.440 \\
\hline & Law & 36 & 3.00 & 1.549 \\
\hline & \begin{tabular}{|l|} 
Sociology \\
\end{tabular} & 66 & 2.73 & 1.431 \\
\hline & Total & 226 & 3.50 & 3.804 \\
\hline
\end{tabular}

Table 4 is showing the descriptive values of ANOVA test. M column shows the mean values of students' responses, enrolled in different programs, for using ICT and their social, personal development, number $\mathrm{f}$ social media they are using and use of internet per day. It is evident that responses of students of business programs showed greater mean score than other disciplines, whereas responses of students in sociology discipline showed least mean score for their social development using ICT. Regarding personal development of students using ICT, responses of students in science discipline showed greater mean score and that of sociology showed least mean score. Table also showing that students in science discipline were using more social media networks and law students used least number of social media networks. Students in science discipline use more internet per hour daily than other disciplines and students of sociology use least number of hours per day. 
Table 5: ANOVA to see Difference on the Basis of Semester

\begin{tabular}{|c|c|c|c|c|c|c|}
\hline \multicolumn{2}{|l|}{ Variables } & Sum of Squares & $\begin{array}{l}\text { Mean } \\
\text { Square } \\
\end{array}$ & df. & $\mathrm{F}$ & Sig. \\
\hline \multirow{3}{*}{ Social Development } & $\begin{array}{l}\text { Between } \\
\text { Groups }\end{array}$ & 856.65 & 171.33 & 5 & 4.03 & .002 \\
\hline & Within Groups & 9876.22 & 42.57 & 232 & & \\
\hline & Total & 10732.87 & & 237 & & \\
\hline \multirow{3}{*}{ Personal Development } & $\begin{array}{l}\text { Between } \\
\text { Groups } \\
\end{array}$ & 764.07 & 152.82 & 5 & 6.72 & .000 \\
\hline & Within Groups & 5274.72 & 22.74 & 232 & & \\
\hline & Total & 6038.79 & & 237 & & \\
\hline \multirow{3}{*}{ Networks in use } & $\begin{array}{l}\text { Between } \\
\text { Groups } \\
\end{array}$ & 79.35 & 15.87 & 5 & 3.02 & .012 \\
\hline & Within Groups & 1051.36 & 5.26 & 200 & & \\
\hline & Total & 1130.70 & & 205 & & \\
\hline \multirow{3}{*}{$\begin{array}{l}\text { Use of internet in } \\
\text { Hours }\end{array}$} & $\begin{array}{l}\text { Between } \\
\text { Groups } \\
\end{array}$ & 77.28 & 15.46 & 5 & 1.05 & .387 \\
\hline & Within Groups & 3166.11 & 14.66 & 216 & & \\
\hline & Total & 3243.39 & & 221 & & \\
\hline
\end{tabular}

Table 5 presents the results of ANOVA to identify semester wise mean difference in students' personal and social development, number of social medias being used by the students and use of internet in hours per day in different programs, e.g. Business, science, law and sociology using ICT. Table revealed that there was significant mean difference in social development $F(5)=4.03, p<.05$ and personal development $\mathrm{F}(5)=6.72, \mathrm{p}<.05$ of students enrolled in different semesters of various programs on the basis of using ICT. There was also significant mean difference in using number of social media networks on the basis of semester in different programs $F(5)=3.03, p<.05$. Although no significant mean difference occur in students' responses enrolled in different semesters on diverse programs of study on the basis of using internet per day $F(5)=1.05, \mathrm{p}<.387$.

Table 6: Descriptive Statistics of AVOVA Test for Mean Difference on the Basis of Semester

\begin{tabular}{|c|c|c|c|c|}
\hline \multicolumn{2}{|l|}{ Variables Semester } & $\mathrm{N}$ & M & SD. \\
\hline \multirow{7}{*}{ Social Development } & 1 & 48 & 26.4167 & 6.73458 \\
\hline & 2 & 34 & 24.3529 & 5.59156 \\
\hline & 3 & 54 & 25.0351 & 6.84329 \\
\hline & 4 & 40 & 31.2000 & 4.34102 \\
\hline & 5 & 38 & 29.7500 & 3.73210 \\
\hline & 7 & 24 & 28.0833 & 7.08284 \\
\hline & Total & 238 & 25.6050 & 6.72952 \\
\hline \multirow{6}{*}{$\begin{array}{l}\text { Personal } \\
\text { Development }\end{array}$} & 1 & 48 & 23.2083 & 4.32685 \\
\hline & 2 & 34 & 18.9412 & 4.17018 \\
\hline & 3 & 54 & 20.6140 & 5.23688 \\
\hline & 4 & 40 & 26.4000 & 3.97772 \\
\hline & 5 & 38 & 28.7500 & 5.41822 \\
\hline & 7 & 24 & 22.5000 & 4.03248 \\
\hline
\end{tabular}




\begin{tabular}{|c|c|c|c|c|}
\hline & Total & 238 & 21.2689 & 5.04778 \\
\hline \multirow{7}{*}{ Networks in use } & 1 & 48 & 2.77 & 2.253 \\
\hline & 2 & 34 & 2.44 & 2.044 \\
\hline & 3 & 54 & 2.17 & 2.059 \\
\hline & 4 & 30 & 3.20 & 1.932 \\
\hline & 5 & 38 & 4.00 & 3.225 \\
\hline & 7 & 22 & 4.00 & 3.352 \\
\hline & Total & 206 & 2.62 & 2.349 \\
\hline \multirow{7}{*}{$\begin{array}{l}\text { Use of internet in } \\
\text { Hours }\end{array}$} & 1 & 48 & 2.65 & 1.595 \\
\hline & 2 & 34 & 2.86 & 1.580 \\
\hline & 3 & 54 & 3.96 & 5.241 \\
\hline & 4 & 38 & 4.40 & 1.265 \\
\hline & 5 & 38 & 3.25 & 1.165 \\
\hline & 7 & 24 & 3.75 & 1.824 \\
\hline & Total & 222 & 3.52 & 3.831 \\
\hline
\end{tabular}

Table 6 is presenting the descriptive values of ANOVA test to identify mean difference in social and personal development of students using ICT, number of social media networks being used by students in various semesters of different programs and use of internet per day by the students of different semesters of different disciplines. M column shows the mean values of students' responses, enrolled in different semesters of different disciplines, for using ICT and their social, personal development, number of social media they are using and use of internet per day. It is evident that responses of students (using ICT) of semester four showed greater mean score than other disciplines, whereas responses of students in semester two showed least mean score for their social development. Regarding personal development of students (using ICT) responses of students in semester four showed greater mean score and responses $\mathrm{f}$ students showed least mean score in semester two. Table also showing that students in semester five and seven were using more social media networks and students in semester two used least number of social media networks. Students in semester four use more internet per hour daily than other disciplines and students of semester one used least number of hours per day.

\section{Discussion and Conclusion}

Results of the data analysis showed that male students using ICT developed socially more than female students. This may be due to different social responsibilities and exposure of students. In Pakistani scenario parents keep a check on social circle of their off springs and especially on girls. They are not allowed to have opposite gender friendships, and can have limited working relations with opposite gender. To some extent boys are free from this check because they can spend leisure time out side home.

This may be the factor of male students more social development than female students. Analysis also revealed that male students using ICT get more personal development than female students. Again this may be parent's check and restricted environment for female students. As compare to male, female students cannot adopt the entire latest fashion trend they found on media. They are expected and liked to follow their values. In our contest it may be a great factor for the difference in personal development of female students. Result of AVOVA test showed that business students using ICT get more personal development. This may be due to their nature of study. They have to do business in society and social skills are more emphasized in business studies. Science students using ICT showed greater mean score for their personal development. Science students are more concerned with their own progress and work and have less concern with others. They interact with latest advancements in science and technology which may be one of the reasons of their personal development.

Greater use of social media by students of sociology depicts that they do more social networking than other disciplines. It is required in the subjects being taught in sociology to be aware of different trends and 
events prevailing in society due to which these students have to use more social media networks. Science students have to do more research work. As we know there is bulk of new knowledge being generated every day. In order to search new and relevant knowledge they have to search more than other students, this is one of the reason that science students are using more internet then others.

So, on the basis of above discussion it may be concluded that it is our values and parental check and expectations that create difference in social and personal development of male and female students. Regarding different programs of study business students' nature of discipline and subjects under study enhance social development of students. Science students have to work hard and they have to keep themselves up to date so they get more personal development. Business and sociology students use more number of social media networks than students in other disciplines. Science students use more internet then students in other disciplines.

\section{Recommendations}

On the basis of findings of the study following recommendations were made:

- Government must increase budget to enhance the use of ICT at higher education level.

- Further research must be initiated to identify potential befits of advanced technology in ICT for education.

- Female students must be appreciated for their social and personal development.

- There must be seminars and workshops for students for their personal and social development by using ICT.

- There must workshops to trained students to use ICT effectively at higher education level.

\section{Reference}

Downes, T., Arthur, L., \& Beecher, B. (2001). Effective learning environments for young children using digital resources: an Australian perspective. Information Technology in Childhood Education Annual, 1, 139-153.

Gale, C.,\& Watson, S. (2002). Is e-learning sustainable? Lesson from webvan. In Ecology of the new economy:sustainable transformation of global information, communication, and electronic industry, (eds. J. Park and N. Room. Sheffield), UK: Greenleaf.

Jonassen, D. H.,\& Reeves,T. C. (1996). Learning with technology: Using computers as cognitive tools. In D. H. Jonassen (Ed.), Handbook of research for educational communications and technology. New York: Macmillan, 693-719.

Lewin, I., Cooper, R., Ericsson, S., \&Rupp, C. (2000). Dialogue moves in negotiative dialogue, project deliverable 1.2. SIRRIDUS, 2000

Passey, D. (1997). Supporting learning in isolated environments. In J. Underwood and J.Brown (eds.) Integrated Learning Systems: Potential into Practice. London: Heinemann.

Pedretti, E., Mayer-Smith, J.,\& Woodrow, J. (1998). Technology, text and talk: Students' perspectives on teaching and learning in a technology-enhanced secondary school classroom. Science Education, 82(5), 569-589.

Warschauer, \& HealeyD. (1998) "Computers and language learning: an overview. Language Teaching, $31,57-71$. 